\title{
KONSEPTUALISASI SOSIOKULTURAL MASYARAKAT SUNDA DALAM METAFORA KONSEPTUAL BAGIAN TUBUH
}

\author{
${ }^{1}$ Hera Meganova Lyra, ${ }^{2}$ Wahya, ${ }^{3} R$. Yudi Permadi \\ ${ }^{123}$ Fakultas Ilmu Budaya, Universitas Padjadjaran, Bandung \\ 1hera.meganova.lyra@unpad.ac.id
}

\begin{abstract}
Abstrak
Dalam tulisan ini dideskripsikan konseptualisasi sosiokultural masyarakat Sunda yang terkandung dalam metafora konseptual bagian tubuh. Digunakan metode deskriptif dan kajian distribusional konseptual semantik kognitif Lakoff dan Johnson (1980) yang dipertegas oleh Konwles \& Rosamund (2006), Kovecses (2010), Saeed (2009) dalam mendeskripsikan dan menganalisis data yang bersumber dari data lisan dan tulisan. Dihasilkan konsep sosiokultural masyarakat Sunda yang terkandung di dalamnya metafora bagian tubuh, yaitu: (1) konsep keadaan (bentuk, tekstur, pancaindera, zat cair, dan suasana); (2) konsep bagian; (3)konsep posisi; (4) konsep wilayah; dan (5) konsep imitasi bentuk.
\end{abstract} Kata kunci: metafora konseptual, bagian tubuh, sosiokultural, dan bahasa Sunda

\section{Abstract}

This article describes the sociocultural conceptualization produced by the Sundanese society as the creators and users of conceptual metaphor of body parts. The descriptive method and distributional study of cognitive-semantics conceptual by Lakoff and Johnson (1980) were used supported by Konwles and Rosamund (2006), Kovecses (2010), and Saeed (2009) in describing and analyzing the data collected from both oral and written data sources. The result shows the sociocultural concept of Sundanese society contained in body parts metaphor, namely: (1) concept of state (form, texture, five senses, liquid substances, and situation); (2) concept of part; (3) concept of position; (4) concept of territory; and (5) concept of form imitation.

Keywords: conceptual metaphor, body parts, sociocultural, and Sundanese language

\section{PENDAHULUAN}

Metafora konseptual pertama kali diperkenalkan oleh Lakoff dan Jhonson (1980). Menurutnya metafora tidak sengaja diciptakan tetapi melebur dalam bahasa keseharian. Tanpa disadari orang akan memumculkan metafora dalam tuturannya. Metafora tersebut timbul dari hasil kontruksi mental, konsepstualiasi pengalaman hidup manusia. Metafora konseptual menjadi kritik terhadap pandangan yang masih menganggap bahwa metafora itu sengaja dibuat dan diciptakan agar tulisan dan hasil karya cipta berkesan indah dan puitis. Menurut Lakoff dan Jhonson metafora hadir dalam kehidupan sehari-hari. Metafora melebur dalam bahasa literal (keseharian), yang terkadang penutur bahasa literal itu tidak menyadari akan hadirnya metafora dalam bahasa yang ia tuturkan. Misalnya saja:

1. Tahun ini keluarga sedang berada dalam kesusahan.

2. Dia sudah bisa keluar dari masalah yang menderanya.

3. Suaranya begitu lembut.

Ketiga kalimat di atas cenderung kita dengar dalam bahasa keseharian. Kita mungkin tidak menyadari dalam ketiga kalimat tersebut terdapat metafora, ada pemetaan dari 
satu bentuk ke bentuk lain atau ada pemetaan dari ranah sumber ke ranah sasaran. Kalimat (1) dan (3) memetaforkan orientasi ruang. Ranah ruang yang berorientasi akan dalam/luar, masuk/keluar, dipetakan pada ranah kesusahan dan masalah. Kesusahan dianggap sebagai suatu ruangan yang bisa membuat sebuah keluarga masuk dan berada di dalamnya. Begitu juga dengan masalah dianggap sebagai sebuah ruangan yang membuat seseorang masuk atau keluar dari masalah itu. Kalimat (3) memetaforkan suara sebagai tektur yang lembut, yang bisa memberikan kenyamanan. Suara yang tidak kasar dan nyaring memberikan kenyamanan untuk yang mendengarnya.

Dalam metafora konseptual ada pemetaan atau transfer dari satu bentuk ke bentuk lain, dari bentuk konkret ke bentuk abstrak. Metafora konseptual menjadi bagian dari sistem berpikir manusia yang terwujudkan dalam bentuk tingkah laku hidupnya sebagai pengalam. Melalui metafora, kita bisa membokar konsep sosiokultural masyarakat pembuat dan penutur metafora tersebut.

Tulisan ini berfokus pada metafora koseptual bagian tubuh dalam bahasa Sunda yang ditikberatkan pada konsep-konsep yang menjadi dasar representasi sistem berpikir masyarakat Sunda sebagai pembuat dan penutur metafora. Bagian tubuh dipilih sebagai sarana metafora konseptual dengan didasarkan pada pandangan filusuf Italia abad ke18, Giambattista Vico yang menyatakan metafora cenderung paling banyak muncul dalam pemetaan bagian tubuh (Sumarsono: 2012). Bahasa Sunda dipilih sebagai objek kajian dengan didasarkan pada kehidupan bahasa Sunda yang masih cenderung baik dibandingkan bahasa daerah lainnya di wilayah Indonesia Timur. Bahasa Sunda masih digunakan sebagai sarana komunikasi di pedesaan. Bahasa Sunda masih digunakan dalam karya sastra seperti puisi, cerpen, novel, dan majalah mingguan Manggle. Selain itu, bahasa Sunda adalah bahasa ibu dan bahasa daerah bagi penulis.

Menurut Saeed (2009: 361-364), sebuah kelompok kata disebut metafora jika memiliki empat karakteristik, yaitu konvensional, sistematis, asimetris, dan abstraksi.

a. Yang dimaksud dengan karakteristik konvensional adalah metafora sudah terkonvensi menjadi lebih umum tanpa disadari menguasai konsep pemikiran kita. Metafora dianggap sebagai bagian dari kosakata literal (kosakata seharihari). Oleh pandangan klasik, metafora ini disebut sebagai metafora mati atau dead methapor (Saeed, 2009:361).

Contoh: $\quad$ My spirits rose

(Saeed, 2009:361)

b. Yang dimaksud dengan sistematik adalah adanya perbandingan antara ranah sumber dan ranah sasaran yang bergabung dalam titik kesamaan yang berkembang dalam logika internal. Sistematik dalam metafora tidak hanya mengambil pemetaan antara ranah sumber dan ranah sasaran, tetapi metafora membangun kerangka logis dari pemetaannya tersebut.

$$
\begin{array}{ll}
\text { Contoh: } & \text { Life is a journey } \\
& \text { (Saeed, 2009:362) }
\end{array}
$$

Dari metafora life is a journey memunculkan kerangka logis yang bersinggungan dengan itu. Kelahiran dipetakan sebagai kedatangan, contohnya: She has on babby on the way. Kematian sebagai kepergiaan, contohnya: she passed away this morning atau he's gone (Saeed, 2009:362).

c. Asimetris kebalikan dari simetris. Jika membandingkan dua konsep, kita harus membandingkan dari arah keduanya (simetris). Tetapi dalam metafora itu tidak berlaku, metafora bersifat asimetris, membandingkan dua objek, hanya dilihat dari satu arah, yaitu ranah sumber.

$$
\text { Contoh: } \quad \text { Life is a journey }
$$$$
\text { (Saeed, 2009: 363) }
$$ 
Metafora life is a journey memetakan konsep kedatangan dan kepergian dari sebuah perjalanan ke kehidupan. Perjalanan merupakan ranah sumber dan kehidupan merupakan ranah sasaran. Pemetaan bersifat asimetris dalam arti hanya membandingkan dari satu arah, yaitu dari arah kehidupan ke perjalanan. Tidak berlaku sebaliknya. Jika dipaksakan untuk dicoba dibandingkan dari perjalanan ke kehidupan, perjalanan menjadi sebuah kelahiran dan kematian, perbandingan menjadi rancu bahkan malah tidak berterima. Our fight was born a few minutes; kedatangan dipetakan sebagai kelahiran atau by the time we got there, the boat had died; kepergian dipetakan sebagai kematian (Saeed, 2009: 363).

d. Karakteristik terakhir, abstraksi, berkaitan dengan metafora menggunakan sumber yang konkret untuk menggambarkan sasaran yang abstrak.

Contohnya: My mind just isn't operating today.

Pikiran yang abstrak dianggap sebagai sebuah mesin yang selalu bekerja, yang kadang-kadang mengalami ganguan juga, yaitu ngadat 'tidak mau bekerja'.

Menurut Lakoff dan Johnson (1980; 2003) yang dipertegas oleh Konwles and Rosamund (2006:33) dan Kovecses (2010:17), metafora konseptual memiliki tiga komponen, yaitu sebagai berikut:

\section{a. Ranah sumber (source domain)}

Ranah ini bersifat konkret. Ranah sumber (source domain) terdiri dari sekumpulan entitas, atribut, atau proses yang terhubung secara harfiah, dan secara semantis terhubung dan tersimpan dalam pikiran. Hal-hal itu diungkapkan melalui seperangkat kata atau ungkapan yang dianggap terhimpun dalam kelompokkelompok yang serupa yang sering disebut linguis sebagai kelompok leksikal (lexical sets) atau bidang-bidang leksikal (lexical fields). Dalam pandangan klasik ranah ini disebut sebagai wahana atau vechile.

b. Ranah sasaran (target domain).

Ranah sasaran (target domain) cenderung bersifat lebih abstrak dan mengikuti struktur yang dimiliki ranah sumber melalui pemetaan. Pemetaan inilah yang disebut metafora konseptual. Oleh karena itu, entitas, atribut, dan proses dalam ranah sasaran diyakini berhubungan satu sama lain seperti pola yang dipetakan dari hubungan entitas, atribut, dan proses dalam ranah sumber. Pada tataran bahasa, seluruh entitas, atribut, dan proses dalam ranah sasaran dileksikalkan melalui kata-kata dan ungkapan dari ranah sumber. Dalam pandangan klasik ranah ini disebut sebagai tenor.

c. Pemetaan (correspondence or mapping)

Pemetaan ini menghasilkan titik kesamaan (ground), yaitu makna yang memperlihatkan persamaan antara sasaran ke sumber. Ini tidak bisa dibalikkan. Dalam pandangan klasik, ini disebut sebagai dasar metafora.

\section{METODE PENELITIAN}

Metode penelitian yang digunakan adalah metode deskriptif dengan teknik penelitian dimulai dari pengumpulan data berupa gabungan kata berunsur bagian tubuh yang diambil dari sumber data novel, majalah, buku, dan kamus. Setelah data terkumpul, dilanjutkan dengan tahap penyeleksian data menjadi korpus data (data yang dipakai sebagai sumber bahan penelitian). Penyeleksian data didasarkan pada prinsip dasar metafora, yaitu adanya pemetaan dari ranah sumber ke ranah sasaran. Data yang memenuhi prinsip dasar metafora kemudian dicatat dalam korpus data. Untuk menguji validitas data tersebut, digunakan teknik triangulasi, yaitu teknik pemeriksaan keabsahan data dengan memanfaatkan sesuatu 
yang lain di luar data itu untuk keperluan pengecekan atau sebagai pembanding terhadap data itu (Moleong, 2011:330). Teknik triangulasi yang digunakan adalah pemeriksaan melalui sumber data lainnya. Tahap penyeleksian, pencatatan, dan pengujian data menjadi korpus dilakukan secara mandiri oleh peneliti. Setelah data teruji validitasnya kemudian dilanjutkan dengan tahap pengklasifikasian data berdasarkan unsur tubuh, konstruksi, konsepsi makna, dan skema citra. Setelah itu dilanjutkan dengan penganalisisan data menggunakan teori yang ada, dan penyimpulan hasil penelitian sebagai jawaban terhadap masalah yang diteliti.

Metode kajian yang digunakan dalam penelitian ini adalah metode kajian distribusional. Teori semantik kognitif digunakan untuk menjawab masalah yang diajukan. Semantik kognitif merupakan pendekatan berdasarkan pengalaman karena itu metafora merupakan bagian dari sistem berpikir manusia yang terealisasikan dalam bentuk tingkah laku hidupnya sebagai experience 'pengalaman' yang berkaitan dengan pengalaman sosiokultural dan historis dari suatu masyarakat. Metafora bukan hanya sekadar gaya bahasa dan sarana retorika.

Dalam merumuskan konsep metafora konseptual bagian tubuh dalam bahasa Sunda, peneliti memetakan konsepsi makna hasil proses pemetaan ranah sumber $(\mathrm{Su})$ ke ranah sasaran (Sr). Pemetaan (Su) ke (Sr) menghasilkan salah satunya adalah konsepsi makna keadaan. Konsepsi makna keadaan dalam metafora bagian tubuh bahasa Sunda dibedakan menjadi keadaan yang berkaitan dengan bentuk, tekstur, pancaindera, dan zat cair. Pemetaan metafora bagian tubuh yang memanfaatkan konsepsi keadaan bentuk diwakili oleh metafora hulu pénjol 'kepala panjul'. Metafora hulu pénjol 'kepala panjul' memetakan konsepsi keadaan bentuk ranah sumber $(\mathrm{Su})$ benda ke ranah sasaran $(\mathrm{Sr})$ bagian tubuh manusia. Unsur penjol 'panjul' menjadi penerang keadaan bentuk bagian tubuh hulu 'kepala'.

\section{HASIL DAN BAHASAN}

\subsection{Konsep Sosiokultural Masyarakat Sunda dalam Metafora Konseptual Bagian Tubuh}

Konsep sosiokultural masyarakat Sunda dalam metafora konseptual bagian tubuh dihasilkan dari konsepsi pemetaaan konsep ranah sumber (Su) ke ranah sasaran (Sr). Konsep sosiokultural masyarakat Sunda dalam metafora konseptual bagian tubuh berjumlah 12 konsep, yaitu: (1) keadaan; (2) bagian; (3) posisi; (4) wilayah; (5) imitasi bentuk ; (6) sifat; (7) warna; (8) cahaya; (9) ukuran; (10) luka; (11) benda tajam; dan (12) suhu. Dalam tulisan ini akan dibahas lima konsep, yaitu keadaan, bagian, posisi, wilayah, dan imitasi bentuk.

\section{Konsep Keadaan}

Konsep keadaan dalam metafora bagian tubuh bahasa Sunda dibedakan menjadi keadaan yang berkaitan dengan bentuk, tekstur, pancaindera, zat cair, dan suasana. Pemetaan metafora bagian tubuh yang memanfaatkan konsep keadaan bentuk diwakili oleh metafora gado méncos 'dagu mencos', béngkok tikoro 'tidak kebagian makanan', dan sirahna buleud 'kepalanya bulat'.

(1) gado méncos

dagu mencos

'dagu mencos'

(2) béngkok tikoro

bengkok kerongkongan

'tidak mendapatkan makanan'

Metafora gado méncos 'dagu mencos' dan béngkok tikoro 'tidak kebagian makanan' memetakan konsep keadaan dari bentuk ranah sumber (Su) benda 
ke ranah sasaran (Sr) bagian tubuh manusia. Unsur méncos 'mencos' dan béngkok 'bengkok' menjadi penerang keadaan unsur bagian tubuh gado 'dagu' dan tikoro 'kerongkongan'. Metafora gado méncos menggambarkan keadaan bentuk dago 'dagu' yang tidak simentris. Metafora béngkok tikoro menggambarkan keadaan bentuk tikoro 'kerongkongan' yang bengkok sehingga makanan tidak bisa masuk ke dalam lambung. Metafora béngkok tikoro bermakna keadaan tidak kebagian makanan.

Pemetaan metafora bagian tubuh yang memanfaatkan konsep keadaan tekstur diwakili oleh metafora beungeutna peungkeur 'wajahnya kenyal dan kencang' dan metafora kulitna karijut 'kulitnya keriput'.
(3) kulitna karijut
kulitnya keriput
'kulitnya keriput'
(4) beungeutna peungkeur
wajahnya kenyal dan kencang
'wajah yang kencang dan kenyal'

Metafora kulitna karijut 'kulitnya keriput' dan beungeutna peungkeur 'wajahnya kenyal dan kencang' memetakan konsepsi keadaan tekstur dari ranah sumber (Su) benda ke ranah sasaran (Sr) bagian tubuh manusia. Unsur karijut 'keriput' dan peukeur 'kencang dan kenyal' menjadi penerang keadaan tekstur unsur bagian tubuh kulit 'kulit' dan beungeut 'wajah'. Metafora kulitna karijut menggambarkan keadaan tekstur kulit' kulit' yang tidak rata, banyak kerutannya. Metafora beungeutna peungkeur menggambarkan keadaan tekstur beungeut 'wajah' yang kencang dan kenyal.

Pemetaan metafora bagian tubuh yang memanfaatkan konsep keadaan pancaindera diwakili oleh metafora bau leungeun 'bau tangan' dan pait daging 'pahit daging'.

(5) bau leungeun

bau tangan

'bau tangan'

(6) pait daging

pahit daging

'kebal, jarang sakit'

Metafora bau leungeun 'bau tangan' dan pait daging 'jarang sakit' memetakan konsepsi keadaan pancaindera dari ranah sumber $(\mathrm{Su})$ keadaan rasa dan bau ke ranah sasaran (Sr) bagian tubuh manusia. Unsur bau 'bau' dan pait 'pahit' menjadi penerang keadaan tekstur unsur bagian tubuh leungeun 'tangan' dan daging 'daging'. Metafora bau leungeun menggambarkan induk burung atau kucing yang tidak mau lagi mengurus anaknya karena telah dipegang oleh manusia. Metafora ini memanfaatkan konsepsi keadaan yang berhubungan dengan pancaindra bau. Ketika manusia memegang anak burung atau kucing maka tangan manusia meninggalkan bau pada hewan itu. Hal tersebut menyebabkan induk burung atau kucing tidak mengenal lagi bau anaknya, yang tercium adalah bau tangan manusia. Metafora pait daging menggambarkan keadaan kulit yang kebal dan tidak mudah terserang penyakit. Metafora pait daging merupakan kebalikan dari metafora amis daging. Untuk rasa pahit, orang cenderung tidak menyukai bahkan menjauhinya. Keadaan kulit yang kebal, tidak mudah terserang penyakit dimetaforkan sebagai rasa kulit yang pahit sehingga penyakit atau luka tidak menyukai dan menjauhi kulit jenis ini.

Pemetaan metafora bagian tubuh yang memanfaatkan konsepsi keadaan zat cair diwakili oleh metafora garing tikoro 'kehausan' dan kentel peujit'sering berpuasa'. 
(7) garing tikoro

kering kerongkongan

'kehausan'

(8) kentel peujit

kental usus

'sering berpuasa'

Metafora garing tikoro 'kehausan' dan kentel peujit 'sering berpuasa' memetakan konsepsi keadaan yang berhubungan dengan zat air dari ranah sumber (Su) keadaan air ke ranah sasaran (Sr) bagian tubuh manusia. Unsur garing 'kering' dan kentel 'kental' menjadi penerang keadaan zat cair unsur bagian tubuh tikoro 'kerongkongan' dan peujit 'usus'. Metafora garing tikoro menggambarkan keadaan manusia yang sedang kehausan. Metafora garing tikoro memanfaatkan pemetaan konsepsi keadaan yang berhubungan dengan zat cair. Keadaan garing 'kering' adalah keadaan yang tidak berair atau tidak basah. Keadaan ini dipetakan pada kondisi manusia yang sedang kehausan. Dalam tubuhnya, cairan menjadi minim sehingga tikoro 'kerongkongan' pun menjadi garing 'kering'. Metafora kentel peujit menggambarkan keadaan manusia yang sedang berpuasa. Metafora ini memanfaatkan pemetaan zat cair. Keadaan kentel 'kental' adalah keadaan kurangnya cairan. Tubuh manusia yang sedang berpuasa tentunya kurang akan cairan. Karena itu, manusia yang berpuasa dimetaforkan sebagai kentel peujit, ususnya kekurangan cairan.

Pemetaan metafora bagian tubuh yang memanfaatkan konsep keadaan suasana dan situasi diwakili oleh metafora harieum beungeut 'suasana menjelang matahari terbenam' dan potong leungeun katuhu 'kehilangan orang yang menjadi tumpuan hidup'.

(9) harieum beungeut remang-remang muka

'sore hari menjelang terbenam matahari'

potong leungeun katuhu

patah tangan kanan

'kehilangan orang yang menjadi tumpuan hidup'

Metaforaharieumbeungeut memetakan konsepsi keadaan suasana harieun'remangremang'. Suasana ini terjadi karena cahaya matahari terhalang oleh pohon-pohon yang tinggi dan lebat. Metafora harieum beungeut menggambarkan suasana remang-remang sehingga yang terlihat hanya wujud tubuh saja sedangkan gambaran wajah secara jelas tidak bisa terlihat. Suasana ini cenderung terjadi pada sore hari menjelang malam dimana cahaya matahari mulai meredup. Metafora potong leungeun katuhu memetakan konsepsi keadaan situasi ketika leungeun katuhu potong 'tangan kanan patah'. Dalam budaya Sunda, tangan kanan cenderung produktif digunakan untuk melakukan berbagai macam aktivitas misalnya makan, menulis, mengetik, membawa sesuatu, dan lain sebagainya. Jika tangan kanan patah, keadaan menjadi timpang karena tangan kanan tidak bisa melakukan fungsinya. Keadaan yang tipang itu kemudian ditransferkan pada ranah sasaran (Sr) keadaan ditinggalkan oleh orang yang dijadikan tumpuan hidup. Keadaan menjadi tidak stabil layaknya tangan tangan kita patah dalam metafora potong leungeun katuhu.

\section{Konsepsi Bagian}

Konsep bagian dipahami sebagai sesuatu yang menjadi pelengkap. Misalnya saja tangan menjadi bagian dari tubuh manusia. Tangan menjadi pelengkap tubuh manusia. Pemetaan metafora bagian tubuh yang memanfaatkan konsepsi bagian diwakili oleh metafora beuheung baju 'leher baju' dan tonggong leungeun 'punggung tangan'. 


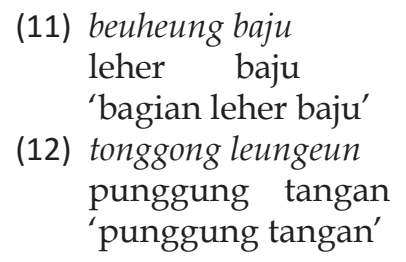

Unsur beuheung 'leher' dan tonggong 'punggung' menjadi penerang bagian unsur baju 'baju', kawung 'pohon aren' dan leungeun 'tangan'. Metafora beuheung baju 'leher baju' memetakan konsepsi bagian dari ranah sumber $(\mathrm{Su})$ bagian tubuh ke ranah sasaran $(\mathrm{Sr})$ benda. Metafora tonggong leungeun 'punggung tangan' memetakan konsepsi bagian dari ranah sumber $(\mathrm{Su})$ bagian tubuh ke ranah sasaran $(\mathrm{Su})$ bagian tubuh. Metafora beuheung baju merupakan bagian dari baju yang berada di di bagian leher. Metafora tonggong leungeun merupakan bagian dari tangan yang bisa ditelungkupkan seperti punggung.

\section{Konsep Posisi}

Konsep posisi dipahami sebagai letak, kedudukan, atau tempat beradanya sesuatu. Pemetaan metafora bagian tubuh yang memanfaatkan konsep posisi diwakili oleh metafora hulu walungan 'hulu sungai', jero haté 'dalam hati', biwir laci 'bagian tepi laci', juru biwir 'sudut bibir', dan suku méja 'kaki meja'.

(13) biwir laci

bibir laci

'bagian tepi laci'

(14) suku méja

kaki meja

'kaki meja'

Unsur biwir 'biwir' dan suku 'kaki' menjadi penerang posisi unsur laci 'laci' dan méja 'meja'. Metafora biwir laci 'bagian tepi laci' dan suku méja 'kaki meja' memetakan konsepsi posisi dari ranah sumber $(\mathrm{Su})$ bagian tubuh ke ranah sasaran ( $\mathrm{Sr}$ ) benda. Metafora biwir laci bermakna bagian tepi dari laci. Metafora ini memetakan konsep posisi dari ranah sumber (Su) biwir 'bibir' manusia yang berada di bagian tepi wajah ke ranah sasaran (Sr) bagian tepi laci. Metafora suku méja 'kaki meja' bermakna bagian bawah meja yang berfungsi menopang tubuh meja. Metafora ini memetakan konsep posisi dari ranah sumber $(\mathrm{Su}) s u k u$ 'kaki' manusia yang berada di posisi bawah yang berfungsi menopang tubuh manusia ke ranah sasaran (Sr) bagian bawah meja.

\section{Konsep Wilayah}

Konsep wilayah dipahami sebagai daerah kekuasaan, pemerintahan, atau pengawasan. Pemetaan metafora bagian tubuh yang memanfaatkan konsepsi wilayah diwakili oleh metafora puseur pamaréntahan 'pusat pemerintahan' dan paruparu kota 'paru-paru kota'.

(15) puseur pamaréntahan

pusar pemerintahan

'pusat pemerintahan'

(16) paru-paru kota

paru-paru kota

'paru-paru kota' 
Metafora puseurpamaréntahan 'pusat pemerintahan' dan paru-paru kota' paru-paru kota' memetakan konsepsi wilayah dari ranah sumber ( $\mathrm{Su}$ ) bagian tubuh ke ranah sasaran (Sr) wilayah. Unsur pamaréntahan 'pemerintahan' dan kota 'kota' menjadi penerang wilayah unsur bagian tubuh paru-paru 'paru-paru' dan puseur 'pusar'. Metafora puseur pamaréntahan bermakna pusat wilayah dimana kepala pemerintahan mengatur pemerintahannya; wilayah ini menjadi denyut kehidupan sebuah pemerintahan. Metafora puseur pamaréntahan memetakan konsepsi wilayah dari ranah sumber (Su) bagian tubuh puseur 'pusat' ke ranah sasaran wilayah pemerintahan (Sr). Bagian tubuh puseur 'pusar' berada di wilayah pusat tubuh dan menjadi denyut kehidupan manusia ketika berada dalam rahim. Konsepsi ini kemudian dipetakan kepada ranah sasaran wilayah, pusat pemerintahan. Metafora paru-paru kota bermakna wilayah yang berfungsi menghasilkan udara yang segar. Metafora ini memetakan konsepsi wilayah dari ranah sumber $(\mathrm{Su})$ paru-paru sebagai organ penghasil udara segar ke ranah sasaran (Sr) wilayah kota yang banyak ditumbuhi pepohonan.

\section{Konsep Imitasi Bentuk}

Konsep imitasi bentuk dipahami sebagai gambaran rupa atau wujud. Misalnya metafora taktak wayangeun ' merupakan gambaran pundak yang rata dan sejajar menyerupai pundak wayang yang rata. Selain taktak wayangeun, metafora bagian tubuh dalam bahasa Sunda yang memetakan konsepsi bentuk adalah ramo mucuk eurih 'jari pucuk ilalang', dan tali ari-ari 'tali ari-ari'.

(17) ramo mucuk eurih

$$
\begin{aligned}
& \text { jari puncuk ilalang } \\
& \text { 'jari pucuk ilalang' } \\
& \text { (18) tali ari-ari } \\
& \text { tali ari-ari } \\
& \text { 'tali ari-ari' } \\
& \text { (19) taktak wayangeun } \\
& \text { pundak wayang } \\
& \text { 'pundak rata dan bagus' }
\end{aligned}
$$

Metafora ramo mucukeurih 'jari lentik' memetakan konsep imitasi bentuk dari ranah sumber $(\mathrm{Su})$ tumbuhan ke ranah sasaran (Sr) bagian tubuh. Metafora taktak wayangeun 'pundak rata dan bagus' dan tali ari-ari 'tali ari-ari' memetakan konsepsi imitasi bentuk dari ranah sumber (Su) benda ke ranah sasaran (Sr) bagian tubuh. Metafora ramo mucuk eurih menggambarkan bentuk jari lentik dan indah menyerupai bentuk pucuk ilalang yang meruncing ke ujung. Metafora ini memetakan konsepsi imitasi bentuk dari ranah sumber $(\mathrm{Su})$ tumbuhan ke ranah sasaran (Sr) bagian tubuh manusia ramo 'jari tangan'. Metafora tali ari-ari 'tali ari-ari' menggambarkan bagian panjang dari ari-ari yang menyerupai tali. Metafora ini memetakan konsepsi imitasi bentuk dari ranah sumber (Su) benda ke ranah sasaran (Sr) bagian tubuh ari-ari 'ari-ari. Metafora taktak wayangeun merupakan gambaran bentuk pundak yang rata, sejajar, dan bagus menyerupai pundak wayang. Metafora ini memetakan konsepsi imitasi bentuk dari ranah sumber (Su) benda wayang ke ranah sasaran (Sr) bagian tubuh taktak 'pundak' manusia.

\section{PENUTUP}

Metafora konseptual menjadi bagian dari sistem berpikir manusia yang terwujudkan dalam bentuk tingkah laku hidupnya sebagai pengalam. Metafora konseptual menjadi gambar konsep sosiokultural masyarakat penutur dan pembuat 
metafora itu. Dalam metafora konseptual bagian tubuh bahasa Sunda, konsep sosiokultural masyarakat Sunda yang terkandung di dalamnya antara lain, yaitu: (1) konsep keadaan (bentuk, tekstur, pancaindera, zat cair, dan suasana); (2) konsep bagian; (3)konsep posisi; (4) konsep wilayah; dan (5) konsep imitasi bentuk.

\section{DAFTAR PUSTAKA}

Cruse, D. Alan dan Croft William. 2004. Cognitive Linguistisc. Cambridge: Cambridge University Press.

Danesi, Marcel. 2011. Pesan, Tanda, dan Makna. Jokjakarta: Jalasutra.

Djajasudarma, T. Fatimah. 1993. Metode Linguistik: Ancangan Metode Penelitian dan Kajian. Bandung. Eresco.

Kahmad, Dadang. 2006. 'Agama Islam dan Budaya Sunda' dalam Ajip Rosidi, Edi S. Ekajati dan A. Chaedar Alwasilah (Penyunting)

Kovecses, Zoltan.2010. Metaphor A Practical Introduction. New York: Oxpord University Press.

Konwles, Murray and Rosamund Moon. 2006..Introducing Methaphor. London and New York: Routledge.

Lakoff, George and Jhonson, Mark.1980.Methaphors We Live By. Chicago:The University of Chicago Press.

Lakoff, George and Jhonson, Mark. 2003.Methaphors We Live By. Chicago: The University of Chicago Press.

Lyra, Hera Meganova. 2015. "Menghidupkan Kembali Metafora Mati Bahasa Sunda dengan Pendekatan Semantik Kognitif" dalam Prosiding Konferensi Internasional Bahasa, Sastra, dan Budaya Daerah Indonesia Halaman 225. Bandung: Universitas Pendidikan Indonesia.

2015. "Aktualisasi Pengalaman Hidup dalam Metafora Orientasional Bagian Tubuh dalam Bahasa Sunda", Prosiding Forum Ilmiah XI (Seminar Internasional Bahasa, Sastra, dan Pembelajarannya): Patriotisme Bahasa dalam Tataran Kebangsaan. Bandung: Fakultas Pendidikan Bahasa dan Sastra - Universitas Pendidikan Indonesia.

2016. “Konsep Ruang dalam Metafora Orientasional Bagian Tubuh dalam Bahasa Sunda" dalam Prosiding Seminar nasional Bahasa Ibu (SNBI) IX halaman 75. Denpasar: Auditorium Widya Sabha Mandala Fakultas Ilmu Budaya Universitas Udayana.

2016. "Perjalanan Tubuh dalam Metafora Orientasional Bahasa Sunda" dalam Prosiding Seminar Tahunan Linguistik (SETALI) 2016 Universitas Pendidikan Indonesia (1-2 Juni 2016). Bandung: Isola Resort, University Training Center, Universitas Pendidikan Indonesia.

2016. "Citra Ruang, Kekuatan, Jalan, dan Bentuk dalam Metafora Orientasional Bagian Tubuh dalam Bahasa Sunda dalam Jurnal Mlangun; Jurnal Ilmiah Kebahasaan dan Kesastraan volume 11 No 1 Juni 2016 (halaman 383). Jambi: Kantor Bahasa Provinsi Jambi.

Saeed, Jhon I. 2003. Semantics. Oxford: Blackwell Publisher Ltd.

Sobarna, Cece. 2012. Preposisi Bahasa Sunda. Bandung: Syabas Book

2013. “Bahasa Sunda di Kecamatan Salem, Kabupaten Brebes Jawa Tengah.

Laporan Penelitian. Fakutas Ilmu Budaya-Unpad: Jatinangor.

Sudaryanto.1992. Metode Linguistik ke Arah Memahami Metode Linguistik. Jogjakarta: Gadjah Mada University Press. 